\title{
ВЕРХНЕУДИНСКАЯ ЯРМАРКА В УСЛОВИЯХ НОВОЙ ЭКОНОМИЧЕСКОЙ ПОЛИТИКИ: ОТ ВОЗРОЖДЕНИЯ К ЛИКВИДАЦИИ
}

\begin{abstract}
Задача быстрого восстановления экономики после гражданской войны потребовала возрождения Верхнеудинской ярмарки. Первые позиции в ярмарочной торговле занимали частные торговцы. Однако, сыграв свою роль в восстановлении товарно-денежных отношений, ярмарочная форма торговли была быстро свернута в соответствии с политикой борьбы с частным капиталом.
\end{abstract}

Ключевые слова: Бурят-Монгольская АССР, Верхнеудинская ярмарка, торговые обороты, новая экономическая политика.

A.M. PLEKHANOVA

\section{VERKHNEUDINSKAYA FAIR UNDER THE CONDITIONS OF NEW ECONOMIC POLICY: FROM LEGALIZATION TO LIQUIDATION}

The task of the fast economic revival after the Civil War claimed the rebirth of the Verkhneudinskaya fair. Leading positions in fair trade were taken by private traders. But having played its role in marketable-monetary relations fair trade was cut down in accordance with the struggle with private capital.

Keywords: Buryat-Mongol ASSR, Verkhneudinskaya fair, trading circulation, new economic policy.

После окончания гражданской войны на смену военному коммунизму, сопровождавшемуся широкомасштабной «красногвардейской атакой» на капитал, пришла новая экономическая политика. Советская власть, стремясь как можно быстрее выйти из состояния глубокого экономического кризиса, вынуждена была вновь допустить рыночные регуляторы в экономику. Одним из механизмов восстановления товарно-денежных отношений в период нэпа стало возрождение ярмарок, игравших значительную роль в торговом обороте России еще в дореволюционный период. На протяжении столетий они встраивались в экономику, адаптируясь к новым социально-экономическим условиям, связывая российские территории в единое целое [9, с. 48]. В условиях новой экономической политики ярмарки заняли заметное место в удовлетворении первичных товарных потребностей населения, поддерживая меновые связи между отдельными экономическими районами. 
В качестве фрормы местного товарооборота ярмарки стали развиваться в отдельных районах нашей страны с первых дней нэпа. В 1922/23 гг. открылось уже до 600 ярмарок. В 1922 г. возникли крупные оптовые ярмарки областного и общегосударственного значения, содействовавшие выявлению как общего размера и структуры спроса, так и имевшихся в стране товарных ресурсов. Декрет СНК от 13 февраля 1923 г., освободив семидневные ярмарки от промыслового налога, повсеместно привел к восстановлению старых и открытию новых ярмарок. Удачный опыт проведения крупных ярмарок в Европейской России (Нижегородская и Ирбитская ярмарки) показал важность использования их в деле регулирования рынка. Особо значительна была организующая роль ярмарок в торговле сельскохозяйственным сырьем и кустарными товарами, а также продукцией несиндицированной местной промышленности [2, с. 86]. Развитие частного предпринимательства в условиях новой экономической политики способствовало сохранению значения ярмарок как регуляторов ценообразования, самых массовых форм взаимодействия товаропроизводителей с торговыми посредниками.

Несмотря на значительную роль ярмарок в удовлетворении товарных потребностей населения, их деятельность, особенно в отдаленных регионах, не изучена еще в полной мере, что исследователи объясняют сложившимся стереотипным мнением о ярмарочном торге, как об отсталой, утратившей былое значение торговой фрорме [2, с. 84]. Задачей данной статьи является исследование истории возрождения и деятельности Верхнеудинской ярмарки, занимавшей лидирующие позиции в ярмарочном рейтинге Забайкалья в дореволюционный период, когда ее торговые обороты составляли от 1,5 до 3 млн р. [5, с. 76].

После окончания гражданской войны в Бурят-Монгольской АССР, образованной Постановлением Президиума ВЦИК РСФСР 30 мая 1923 г., были восстановлены и действовали в г. Верхнеудинске - Верхнеудинская ярмарка, в Хоринском аймаке - Анинская, в г. Баргузине - Ленско-Баргузинская, в Агинском аймаке - Агинская и др. В условиях бездорожья, удаленности от крупных торговых центров и путей сообщения, низкой плотности населения (1,4 чел. на 1 км² [7, л. 42]), а также недостаточной товарности хозяйства ярмарочная торговля в республике вновь приобрела важное значение.

Верхнеудинская ярмарка возобновила свою работу 31 января 1924 г. Нарком промышленности и торговли Бурят-Монгольской АССР И.А. Ильин, выступая на открытии ярмарки, указал, что в отличие от дореволюционной - «старой» - ярмарки, где «главными воротилами были «Второвы» и им подобные», в «новой» - советской - «главное участие принимает рабоче-крестьянское государство в лице своих хозяйственных и торговых органов». Председатель ярмарочного комитета Рубенчик в своем приветственном слове отметил, что главная задача 
ярмарки - «смычка города с деревней, ибо здесь крестьянин найдет место сбыта своего продукта и рабочий обменяет продукт своего труда на продукт сельского хозяйства без вмешательства спекуляции» [6, с. 3].

В качестве участников ярмарки зарегистрировалось 22 торговых учреждения, из которых большая часть прибыла из Иркутска, в том числе Иркутский рабочий производственный кооператив «Игла» и Иркутское отделение всероссийского синдиката «Швейпром». Участникам ярмарки были предоставлены значительные льготы: они отчисляли в пользу ярмарочного комитета лишь 6 \% от стоимости товаров, из которых 1,5 \% поступало в фонд помощи беспризорным детям, 1 \% - на развитие воздушного флота, 0,5 \% - в пользу инвалидов, 1 \% - милиции в виде компенсации за интенсивную охрану района ярмарки. На время ярмарки в городе был организован усиленный санитарно-ветеринарный надзор за состоянием постоялых дворов, за содержанием скота [6, с. 3].

В 1925 г. Верхнеудинская ярмарка прошла еще более оживленно. Ярмарочный торг длился 21 день. В ярмарке приняли участие 103 торговые фрирмы: 16 государственных организаций, из которых 9 местных и 7 приезжих из Иркутска и Канска, 7 кооперативных и 80 частных. Доля участия частного капитала в торговом обороте Верхнеудинской ярмарки выразилась в размере 13 \% (174 141 р.), кооперативных организаций 25 \% (332 988 р.), государственных - 62 \% (842 145 р.) [3, с. 5]. Торговый оборот ярмарки в 1925 г. составил 1349274 р., основное место в котором заняли хлеб и фураж - 320271 р., сырье, главным образом, пушнина, - 200237 р., бакалейные и колониальные товары - 169903 р., москательно-химические - 114179 р., текстильные - 81276 р. [1, с. 77].

Однако уже в 1926 г. ярмарочный торг в столице республике резко сдал свои позиции. По материалам ярмарочного комитета в качестве участников зарегистрировалась 101 организация, из которых 88 частных. Однако из крупных были представлены только два павильона кооперативных организаций - Буркоопсоюз и ЦРК «Единение», основное же место занимала мелкая торговля, «так называемая барахолка, украшенная пряниками и конфектами». Сельское население в ярмарке практически не участвовало. Сделки совершались только за наличный расчет (в отличие от дореволюционного периода, когда закупка товаров осуществлялась преимущественно в кредит) [4, с. 422]. Преобладающей была розничная торговля, оптовый товар носил случайный характер, поэтому играл незначительную роль. Оборот торгующих составил 193317 р. Рупор советской республиканской печати констатировал, что «несмотря на шумиху, поднятую в торговом мире о том, что Верхнеудинская ярмарка имеет краевое значение, как сырьевая ярмарка, результаты ее в этом году очень плачевны. С трудом и натяжкой ее можно будет назвать ярмаркой лишь местного значения» [10, с. 8]. Причинами неудач ярмарочного торга в 1926 г., по мнению современников, стали не 
только запоздалая подготовка к ярмарке и неурожай пшеницы, но и организованные в сельской местности государственными и кооперативными организациями кампании по заготовке сельскохозяйственного сырья, которые снимали большую часть крестьянского предложения. Кроме того, на судьбу Верхнеудинской ярмарки оказал влияние ежегодно увеличивающийся охват сельских районов более модернизированными стационарными - формами государственно-кооперативной торговли.

Как и большинство советских ярмарок в период нэпа, Верхнеудинская имела двойственный характер, с одной стороны, способствуя восстановлению народного хозяйства через развитие товарооборота на началах свободной торговли, с другой, являясь механизмом непосредственной связи деревни с городом [2, с. 86]. Одновременно через ярмарочные торги государство вело борьбу с посредниками в лице частного капитала.

Несмотря на сохраняющийся товарный голод (в 1927-1928 гг. потребности населения в хлопчатобумажных тканях были удовлетворены на 50 \%, в металлоизделиях - на 62 \%, в чае - на $40 \%$ ), дальнейшая необходимость в ярмарках отпала, прежде всего, по идеологическим причинам [8, л. 337]. Наличие ярмарочного торга, предоставлявшего широкое поле деятельности для частного предпринимательства, противоречило развернувшейся со второй половины 1920-х гг. политике, направленной на борьбу с частным капиталом. Отказ от нэпа и свертывание частного предпринимательства привели сначала к сокращению числа ярмарок и снижению их торговых оборотов, а потом и к прекращению их деятельности, что стало отражением в целом советской экономической политики, отвергнувшей рыночные отношения и разнообразие форм собственности в пользу централизованной планово-распределительной системы. Сыграли свою роль и экономические причины. В условиях планового хозяйства, при окрепшей кооперативной сети, большинство ярмарок потеряли свое значение, поскольку цены на них были сопоставимы с ценами в сельской кооперации. В 1930-е гг. ярмаркам как «материальному воплощению хищнического рынка» была объявлена война, что буквально проявилось в разрушении оборудованных ярмарочных площадей с торговыми помещениями и торговыми улицами [9, с. 51]. «Ярмарочный ренессанс» в советском государстве оказался непродолжительным по времени. Верхнеудинская ярмарка, возрожденная в период нэпа, сыграла роль в восстановлении товарно-денежных отношений, но уже не занимала столь значительное место в экономике региона, как это было в дореволюционный период.

\section{Список использованной литературы и источников}

1. Бурят-Монгольская АССР. Очерки и отчеты. 1925-1926. - Верхнеудинск : Госплан БМ АССР, 1927. - 224 с. 
2. Дроздков А. В. Создание рыночной инфраструктуры в Сибири в условиях нэпа (1921-1923 гг.) / А. В. Дроздков // Известия Алтайского государственного университета. - 2012. - Вып. 4-1 (76). - С. 81-88.

3. Итоги Верхнеудинской ярмарки // Бурят-Монгольская правда. - 1925. № 87 (479).

4. Кальмина Л. В. Верхнеудинская ярмарка как социокультурный феномен / Л. В. Кальмина // Иркутский историко-экономический ежегодник: 2015. - Иркутск : Изд-во БГУЭП, 2015. - С. 420-426.

5. Кальмина Л. В. «Покупателей... съехалась масса, и торговля была оживленной» (Забайкальская ярмарочная торговля в последней четверти XIX - начале XX в.: динамика и специфика) / Л. В. Кальмина // Республике Бурятия 95 лет : сб. науч. ст. - Улан-Удэ : Изд-во БНЦ СО РАН, 2018. — С. 76-78.

6. Открытие первой Бурят-Монгольской ярмарки // Бурят-Монгольская правда. - 1924. - № 27 (125). — С. 3.

7. Российский государственный архив социально-политической истории (РГАСПИ). - Ф. 17. - ОП. 67. - Д. 30.

8. РГАСПИ. - Ф. 17. - Оп. 21. - Д. 562.

9. Щеглова Т. К. Ярмарки и ярмарочная деятельность как формы развития сибирских территорий в прошлом и настоящем: исторические и пространственные конфигурации в XIX - начале XXI в. / Т. К. Щеглова // Экономическое развитие Сибири : материалы Сибирского исторического форума, Красноярск, 12-13 октября 2016 г. - Красноярск : Резонанс, 2016. - С. 48-53.

10. Ярмарка не удалась // Бурят-Монгольская правда. - 1926. № 62 (755). - C. 8.

\section{Информация об авторе}

Плеханова Анна Максимовна - доктор исторических наук, заместитель директора по научной работе, Институт монголоведения, буддологии и тибетологии Сибирского отделения РАН, 670047, г. Улан-Удэ, ул. Сахьяновой, 6; e-mail: plehanova.am@mail.ru

\section{Author}

Anna M. Plekhanova - Doctor of History, Deputy Director for Science, Institute for Mongolian, Buddhist and Tibetan Studies of Siberian Branch of Russian Academy of Sciences, 6 Sakhyanova St., 670047, Ulan-Ude, Russia; e-mail: plehanova.am@mail.ru 